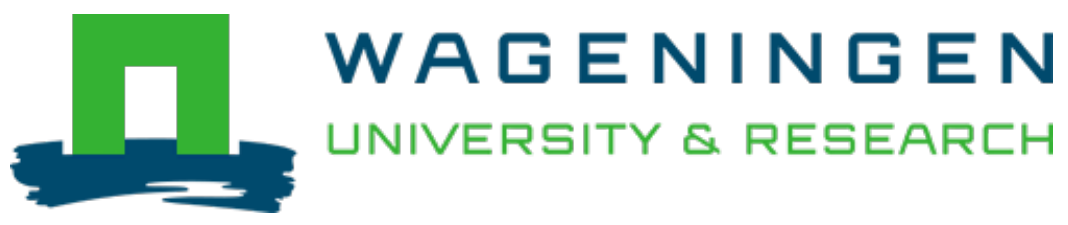

\title{
Bacterial concentration and diversity in fresh tropical shrimps (Penaeus notialis) and the surrounding brackish waters and sediment
}

\author{
International Journal of Food Microbiology \\ Dabade, S.; Wolkers-Rooijackers, J.C.M.; Azokpota, P.; Hounhouigan, D.J.; Zwietering, M.H. et al \\ https://doi.org/10.1016/j.ijfoodmicro.2015.11.013
}

This publication is made publicly available in the institutional repository of Wageningen University and Research, under the terms of article $25 \mathrm{fa}$ of the Dutch Copyright Act, also known as the Amendment Taverne. This has been done with explicit consent by the author.

Article 25 fa states that the author of a short scientific work funded either wholly or partially by Dutch public funds is entitled to make that work publicly available for no consideration following a reasonable period of time after the work was first published, provided that clear reference is made to the source of the first publication of the work.

This publication is distributed under The Association of Universities in the Netherlands (VSNU) 'Article $25 \mathrm{fa}$ implementation' project. In this project research outputs of researchers employed by Dutch Universities that comply with the legal requirements of Article $25 \mathrm{fa}$ of the Dutch Copyright Act are distributed online and free of cost or other barriers in institutional repositories. Research outputs are distributed six months after their first online publication in the original published version and with proper attribution to the source of the original publication.

You are permitted to download and use the publication for personal purposes. All rights remain with the author(s) and / or copyright owner(s) of this work. Any use of the publication or parts of it other than authorised under article $25 \mathrm{fa}$ of the Dutch Copyright act is prohibited. Wageningen University \& Research and the author(s) of this publication shall not be held responsible or liable for any damages resulting from your (re)use of this publication.

For questions regarding the public availability of this publication please contact openscience.library@wur.nl 


\title{
Bacterial concentration and diversity in fresh tropical shrimps (Penaeus notialis) and the surrounding brackish waters and sediment
}

\author{
D. Sylvain Dabadé a,b, Judith C.M. Wolkers-Rooijackers ${ }^{\mathrm{b}}$, Paulin Azokpota a ${ }^{\mathrm{a}}$, D. Joseph Hounhouigan ${ }^{\mathrm{a}}$, \\ Marcel H. Zwietering ${ }^{\mathrm{b}}$, M.J. Rob Nout ${ }^{\mathrm{b}}$, Heidy M.W. den Besten ${ }^{\mathrm{b}, *}$
}

a Laboratoire de Biochimie Microbienne et de Biotechnologie Alimentaire, University of Abomey-Calavi, 01 B.P. 526 Cotonou, Benin

${ }^{\mathrm{b}}$ Laboratory of Food Microbiology, Wageningen University, P.O. Box 17, 6700 AA Wageningen, The Netherlands

\section{A R T I C L E I N F O}

\section{Article history:}

Received 3 July 2015

Received in revised form 19 November 2015

Accepted 22 November 2015

Available online 2 December 2015

\section{Keywords:}

Tropical fishery products

Invertebrates microbiota

Clone libraries analysis

PCR-DGGE

\begin{abstract}
A B S T R A C T
This study aimed at determining bacterial concentration and diversity in fresh tropical shrimps (Penaeus notialis) and their surrounding brackish waters and sediment. Freshly caught shrimp, water and sediment samples were collected in Lakes Nokoue and Aheme in Benin (West Africa) during two periods with different water salinity and temperature. We used complementary culture-dependent and culture-independent methods for microbiota analysis. During both sampling periods, total mesophilic aerobic counts in shrimp samples ranged between 4.4 and $5.9 \log \mathrm{CFU} / \mathrm{g}$ and were significantly higher than in water or sediment samples. In contrast, bacterial diversity was higher in sediment or water than in shrimps. The dominant phyla were Firmicutes and Proteobacteria in shrimps, Firmicutes, Proteobacteria, and Actinobacteria in water, and Proteobacteria and Chloroflexi in sediment. At species level, distinct bacterial communities were associated with sediment, water and shrimps sampled at the same site the same day. The study suggests that the bacterial community of tropical brackish water shrimps cannot be predicted from the microbiota of their aquatic environment. Thus, monitoring of microbiological quality of aquatic environments might not reflect shrimp microbiological quality.
\end{abstract}

(c) 2015 Elsevier B.V. All rights reserved.

\section{Introduction}

Tropical brackish waters are endowed with highly diversified aquatic resources, which play a vital role in providing animal protein and income for the population (Adite and Van Thielen, 1995; Villanueva et al., 2006). Shrimps (Penaeus spp.) are one of the fishery products caught from brackish waters, processed and exported to Europe as frozen shrimp (Dabadé et al., 2014; Ziegler et al., 2011). Ensuring shrimp quality and safety for export is a big concern to shrimp stakeholders. The type and concentration of bacteria associated with a frozen product depend not only on the conditions under which the product is handled and stored but also on the initial product quality (Laplace-Builhé et al., 1993). Shrimps die soon after being caught and they can be contaminated with bacteria from their endogenous microbiota as well as from their environment (Jaffres et al., 2009).

The documented microbiota of freshly caught shrimps varies according to shrimp species and origins. For example, Vanderzant et al. (1971) found that coryneform bacteria were the dominant microorganisms in pond-reared shrimps (Penaeus aztecus) from the west Galveston Bay

\footnotetext{
* Corresponding author.

E-mail address: Heidy.denBesten@wur.nl (H.M.W. den Besten).
}

(USA). Flavobacterium and Planococcus were found to be the most dominant microorganisms associated with Penaeus shrimps harvested from Florida's coasts (USA) (Alvarez, 1983). Moraxella, Micrococcus and Pseudomonas were the dominant microorganisms in fresh shrimps (Penaeus merguiensis) harvested in Pakistan tropical waters (Shamshad et al., 1990). Using culture-independent methods, Liu et al. (2011) showed that Vibrio species were the most abundant microorganisms in the intestinal tract of Chinese shrimps (Fenneropenaeus chinensis). Chaiyapechara et al. (2012) found differences in the microbiota of the intestinal tract of shrimps (Penaeus mondon) reared at the same site in Thailand, but the dominant microorganisms were Vibrio, Photobacterium, or Aeromonas.

To check for shrimp contamination, microbiological analysis is performed mainly on processed shrimps using plating methods (FVO, 2003). Thus, little is known about the diversity and concentration of bacteria associated with freshly caught shrimps. In this study, we aimed at determining bacterial diversity and concentration in shrimps (Penaeus notialis) caught from tropical brackish waters using a combination of culture-dependent and culture-independent approaches. The relationship between the microbiota of the shrimps and that of the surrounding waters and sediment was also investigated. Knowledge of the types of bacteria associated with shrimp and their initial concentrations is of importance to develop strategies and tools for a better shrimp quality and safety management. 


\section{Materials and methods}

\subsection{Field sites and sample collection}

The main shrimp fishing areas in Benin, i.e. Lake Nokoue and Lake Aheme (Dabadé et al., 2014) were targeted. Lake Nokoue $\left(6^{\circ} 20^{\prime}-\right.$ $6^{\circ} 30^{\prime} \mathrm{N}, 2^{\circ} 20^{\prime}-2^{\circ} 35^{\prime} \mathrm{E}$ ) has $150 \mathrm{~km}^{2}$ surface area and a depth of $1-3 \mathrm{~m}$ (Gadel and Texier, 1986; Villanueva et al., 2006). Lake Aheme $\left(6^{\circ} 20^{\prime}-\right.$ $6^{\circ} 40^{\prime} \mathrm{N}, 1^{\circ} 55^{\prime}-2^{\circ} \mathrm{E}$ ) has $85 \mathrm{~km}^{2}$ surface area and a depth of $1-2.2 \mathrm{~m}$ (Maslin and Bouvet, 1986; Maslin and Pattee, 1989). Both lakes are connected with the Atlantic Ocean as well as to rivers (fresh water) from the North (Fig. S1). The salinity of the lakes varies from close to $0 \%$ 。 during the flood season of the rivers up to $30 \%$ o when the rivers recede (Lalèyè et al., 2003; Maslin and Bouvet, 1986). Water, sediment and shrimps were collected from three sites in Lake Nokoue and two sites in Lake Aheme in August 2011 (Fig. S1). In June 2012, two of the three sites in Lake Nokoue sampled in 2011 (N1 and N3, Fig. S1) and one of the two sites in Lake Aheme sampled in 2011 (A1, Fig. S1) were again sampled. The choice of the sites sampled in June 2012 was based on the comparison of the preliminary results (bacterial counts and DGGE profiles) of the sites sampled in August 2011. In each sampling site, water, sediment and shrimps were sampled in duplicate from two spots (four samples of each water, sediment and shrimp per site). Shrimps were collected directly from the fishing nets using sterile hand gloves, and put in sterile polyethylene bags. The gloves were changed between samples. Water samples were collected at $50 \mathrm{~cm}$ below the water surface and the sediments were collected at their surface. The water parameters measured included salinity, $\mathrm{pH}$ and temperature (Table 1). Collected samples were immediately cooled on ice and transported to the laboratory to arrive within $2 \mathrm{~h}$.

\subsection{Enumeration and isolation of microorganisms}

Whole shrimps (2-3 individuals per sample) were aseptically cut into small pieces. Cut shrimps or sediment samples of $25 \mathrm{~g}$ each were transferred aseptically to stomacher bags and diluted 10 times in physiological saline peptone solution $(0.85 \% \mathrm{NaCl}$ (SIGMA, St. Louis, MO, USA), $0.1 \%$ peptone (OXOID, Basingstoke, UK)). The mixture was homogenized for $60 \mathrm{~s}$ using a stomacher (Seward Laboratory Stomacher 400 , England) to obtain the primary dilution from which appropriate decimal dilutions were prepared. For the water samples, decimal dilutions were prepared directly from the samples.

Aerobic mesophilic plate counts were enumerated on plate count agar (PCA, OXOID) incubated at $30{ }^{\circ} \mathrm{C}$ for $48 \mathrm{~h}$ and were reported as total viable count (TVC). Enterobacteriaceae were enumerated on pour plates of violet red bile glucose (VRBG, OXOID) agar overlaid with the same medium, incubated at $37^{\circ} \mathrm{C}$ for $24 \mathrm{~h}$. Oxidase and glucose fermentation tests were carried out on presumptive colonies of Enterobacteriaceae and confirmed counts were reported as Enterobacteriaceae. Pseudomonas spp. were enumerated on spread plates of Pseudomonas agar base (OXOID) supplemented with cetrimide, fucidin, and cephaloridine (CFC) (OXOID), incubated at $25^{\circ} \mathrm{C}$ for $48 \mathrm{~h}$. Oxidase test was performed on presumptive colonies of Pseudomonas spp. and confirmed counts were reported as Pseudomonas spp. Vibrio spp. were enumerated on spread plates of thiosulfate citrate bile salt sucrose agar (TCBS,

Table 1

Parameters of the lake waters during sampling in June and in August (mean \pm standard deviation).

\begin{tabular}{lccccc}
\hline \multirow{2}{*}{ Parameters } & August $(2011)$ & & June $(2012)$ & \\
\cline { 2 - 3 } & $\begin{array}{l}\text { Lake Nokoue } \\
(n=12)\end{array}$ & $\begin{array}{l}\text { Lake Aheme } \\
(n=8)\end{array}$ & & $\begin{array}{l}\text { Lake Nokoue } \\
(n=8)\end{array}$ & $\begin{array}{l}\text { Lake Aheme } \\
(n=4)\end{array}$ \\
\hline Salinity (\%) & $2.5 \pm 0.5$ & $2.9 \pm 0.6$ & & $12.9 \pm 0.1$ & $13.8 \pm 0.5$ \\
$\mathrm{pH}$ & $7.6 \pm 0.2$ & $7.7 \pm 0.1$ & & $7.7 \pm 0.2$ & $7.8 \pm 0$ \\
Temperature $\left({ }^{\circ} \mathrm{C}\right)$ & $24.2 \pm 0.4$ & $24.8 \pm 0.3$ & & $26.8 \pm 0.3$ & $27.0 \pm 0.4$ \\
\hline
\end{tabular}

OXOID) incubated at $30^{\circ} \mathrm{C}$ for $72 \mathrm{~h} . \mathrm{H}_{2} \mathrm{~S}$-producing bacteria were enumerated on double layered plates of Iron Agar supplemented with $0.04 \%$ L-cysteine (SIGMA) as previously described (Gram et al., 1987). Iron agar plates were incubated at $25{ }^{\circ} \mathrm{C}$ for $72 \mathrm{~h}$ and black colonies were counted as $\mathrm{H}_{2} \mathrm{~S}$-producing bacteria. To enumerate spore forming bacteria, $5 \mathrm{~mL}$ of the primary dilution of shrimp or sediment samples and $5 \mathrm{~mL}$ of water samples were heated in sterile tubes for $10 \mathrm{~min}$ at $80^{\circ} \mathrm{C}$ to kill vegetative cells. Appropriate decimal dilutions were made from the heated samples. Spore forming bacteria were enumerated on plate count agar (PCA, OXOID) with overlay of $1.5 \%$ agar and incubated at $30^{\circ} \mathrm{C}$ for $48 \mathrm{~h}$. Lactic acid bacteria (LAB) were enumerated on doublelayered plates of de Man, Rogosa and Sharp agar (MRSA) (OXOID) incubated at $30^{\circ} \mathrm{C}$ for $72 \mathrm{~h}$. Gram stain and catalase test were performed to confirm LAB, and confirmed counts were reported as LAB. Counts were made in the four samples from each site and the results were expressed as the means \pm standard deviation $(n=4)$.

Also, from PCA plates, colonies were picked randomly and streaked onto tryptone soya agar (TSA) (OXOID) plates for purification. For further molecular identification, purified colonies were stored at $-80^{\circ} \mathrm{C}$ in $30 \%$ glycerol and tryptone soya broth, except for LAB, which were stored in 30\% glycerol and MRS broth.

\subsection{DNA extraction}

Genomic DNA was extracted from sediment samples (10 g wet weight per sample) using UltraClean Mega Prep Soil DNA kit (Mo Bio Laboratories, Inc., Solana Beach, CA, USA) following the manufacturer's protocol. The UltraClean water DNA Isolation kit (0.22 $\mu \mathrm{m}$ filters) (Mo Bio Laboratories, Inc., Loker Ave West, Carlsbad, CA, USA) was used to extract genomic DNA from water samples. The water samples were first filtered using $0.22 \mu \mathrm{m}$ filters and the DNA extraction was performed following the manufacturer's protocol. Microbial genomic DNA extraction from whole shrimp matrix was performed by a combination of low and high speed centrifugation protocol followed by DNA purification using DNeasy Tissue Kit (Qiagen, Westburg b.v., The Netherlands) as previously described (Hovda et al., 2007; Rudi et al., 2004). DNA extraction from colonies randomly isolated from PCA was performed following the protocol described in the genomic DNA purification kit (Promega Corporation).

\section{4. $P C R$ and DGGE analysis}

In each sampling site, water, sediment and shrimps were sampled in duplicate from two spots, and the genomic DNA isolated from the duplicate samples (per spot) was pooled per site. The genomic DNA was used as template to amplify the V6-V8 region of the conserved 16S rRNA gene of bacteria using the set of primers previously described (Nubel et al., 1996). PCR mixture of $50 \mu \mathrm{l}$ was made by addition of $1 \mu \mathrm{l}$ of DNA template and $0.4 \mu \mathrm{M}$ of each primer to a ready-to-use solution PCR master mix (Promega Corporation). The amplification conditions were as follows: initial denaturation of double stranded DNA at $94{ }^{\circ} \mathrm{C}$ for $5 \mathrm{~min}$, then 35 amplification cycles with denaturation at $94^{\circ} \mathrm{C}$ for $20 \mathrm{~s}$, primer annealing at $56{ }^{\circ} \mathrm{C}$ for $20 \mathrm{~s}$, and extension at $72{ }^{\circ} \mathrm{C}$ for $1 \mathrm{~min}$, and a final extension at $72{ }^{\circ} \mathrm{C}$ for 7 min followed by cooling at $4{ }^{\circ} \mathrm{C}$. DGGE was applied to the PCR products using the Dcode System apparatus (Bio-Rad) as previously described (Martin et al., 2007; Muyzer et al., 1993). The DGGE gels were silver-stained as previously described (Sanguinetti et al., 1994), dried overnight at $55^{\circ} \mathrm{C}$ and digitized using a GS 800 calibrated Densitometer (BioRad).

Digitized DGGE gels were analyzed using BioNumerics software 7.1 (Applied Maths, Belgium). The DGGE gels were normalized and a band matching analysis was performed. Similarity and dendrogram of the DGGE profiles were created based on the Dice correlation coefficient and unweighted pair-group method with arithmetic averages (UPGMA). To assess the structural diversity of microbial community, Shannon index $\left(\mathrm{H}^{\prime}\right)$ and Simpson index (1-D) were calculated as 
previously described (Thavamani et al., 2012) assuming that each band is a bacterial species (Rahman et al., 2014)

$H^{\prime}=-\sum\left[p_{i} \times \ln \left(p_{i}\right)\right]$

$1-D=1-\sum p_{i}^{2}$

In both equations, $P_{i}={ }^{n_{i}} /{ }_{N}$, with $n_{i}$, the height of the peak, which corresponds to the band intensity in the densitometric curves and $N$, the sum of all peak heights of the bands in the densitometric curves.

The PCR conditions described above were also used to amplify the 16S rRNA gene of bacterial DNA extract from colonies randomly selected from PCA plates using 8F (5'-AGA GTT TGA TCC TGG CTC AG-3') and 1522R ( 5'-AAG GAG GTG ATC CAG CCG CA-3') universal primers as previously described (Lima et al., 2012).

\subsection{Clones libraries construction}

Three clone libraries were constructed for shrimp samples: two clone libraries for shrimp samples collected from the same site (N1) in Lake Nokoue during August and June sampling, respectively, and one clone library for shrimp samples collected during June sampling from the site (A1) in Lake Aheme. To obtain insight into the relationship between the microbiota of shrimps and that of their surroundings, two clone libraries were constructed for water and sediment samples, respectively collected at the same site (N1) and the same day (June sampling) as the shrimp samples.

For each site, genomic DNA from the four samples was pooled. Amplified 16S rRNA gene using $8 \mathrm{~F}$ and $1522 \mathrm{R}$ universal primers was purified and cloned in Escherichia coli JM109 High Efficiency Competent Cells (Promega) as described by Lima et al. (2012). The expected size (approximately $1500 \mathrm{bp}$ ) of the insert in recombinant colonies was checked by PCR using T7 and Sp6 pGem-T-specific primers as previously described (Lima et al., 2012). At least 96 clones were randomly selected for each clone library. An exception was the clone library for the shrimp samples collected from Lake Nokoue in August where only 60 clones were selected due to an insufficient number of recombinant colonies.

\subsection{Sequencing}

Clones (480 in total) and the PCR products of the bacterial isolates from the PCA plates (38) were sequenced (GATC Biotech) with the bacterial universal primer 27F (5'-AGAGTTTGATCMTGGCTCAG-3').

\subsection{Sequences analysis}

The sequences were trimmed to 800 bp using Chromas v. 2.31 (Technelysium Pty Ltd.). Chimeric sequences were removed from the clone libraries and bacterial isolate sequences using DECIPHER (Wright et al., 2012). The Ribosomal Database (RDP) Classifier version 2.6, a naive Bayesian classification method (Wang et al., 2007) was used to perform taxonomic classification of the clone libraries sequences at $80 \%$ confidence threshold. The open-source software MOTHUR (Schloss et al., 2009) version 1.33 was used to assign the sequences to operational taxonomic units (OTUs) based on $97 \%$ sequences similarity cutoff ( 0.03 distance threshold). Shannon index of diversity $\left(H^{\prime}\right)$ and Simpson index of diversity $(1-D)$ were determined using MOTHUR. The percentage of coverage of the clone libraries was calculated using Eq. (3). (Bai et al., 2012; Bekele et al., 2011).

$C=[1-(n / N)] \times 100$

where $C$ is the library coverage (in percentage), $n$ is the number of singletons and $N$ is the total number of sequences.

The representative sequence of each OTU was compared against the GenBank database using the basic local alignment search tool (BLAST)
(Altschul et al., 1990). Phylogenetic analyses were conducted using MEGA 5.1 (Tamura et al., 2011) for shrimp clone libraries. The neighbor-joining method based on distance estimates calculated by the Jukes-Cantor model was used to construct a phylogenetic tree, which was bootstrap resampled 1000 times.

\subsection{Statistical analysis}

The difference in average levels of the groups of microorganisms enumerated was assessed using a Student's two-tailed t-test or oneway ANOVA (IMB SPSS Statistics 19.0) followed by Tukey's test as post hoc comparison of means. Significance was accepted at $P<0.05$.

\subsection{Nucleotides sequences accession numbers}

The sequences obtained in this study have been deposited in the GenBank under the accession numbers KP181616-KP181650 (isolates) and KP181651-KP182059 (clones).

\section{Results}

\subsection{Enumeration of bacterial groups}

Microbial concentrations in shrimp, water and sediment samples are presented in Fig. 1. For shrimps sampled in August the average concentration of aerobic plate counts reported as total viable counts (TVC) varied between 4.4 and $5.4 \log$ colonies forming unit (CFU)/g (Fig. 1A). The concentrations of Pseudomonas spp. and Vibrio spp. were similar and varied between 3.6 and $4.5 \log \mathrm{CFU} / \mathrm{g}$. The concentration of $\mathrm{H}_{2} \mathrm{~S}$ producing bacteria ranged between 3.2 and $4.0 \log \mathrm{CFU} / \mathrm{g}$, and for $\mathrm{En}$ terobacteriaceae the concentration varied between $1.4 \mathrm{log} \mathrm{CFU} / \mathrm{g}$ in sample A1-Aug. and $3.2 \log \mathrm{CFU} / \mathrm{g}$ in sample N3-Aug. The average concentration of the different groups of microorganisms was significantly higher in shrimp than in water (Fig. 1B) or sediment (Fig. 1C), except for spore forming bacteria whose concentration was significantly higher in sediment.

In general, the average concentration of the different groups of microorganisms in shrimp or water samples was higher in June than in August. The difference in the average concentration of the different groups of microorganisms in sediment during both periods was however less clear. During both periods, LAB average concentrations varied between 3 and $4 \log$ CFU/g in shrimp to below detection limit ( $1 \log \mathrm{CFU} / \mathrm{g}$ in sediment samples and $0 \log \mathrm{CFU} / \mathrm{ml}$ in water samples) in water and sediment samples.

\subsection{Bacterial community analysis by PCR-DGGE}

DGGE patterns of the duplicate samples from the same site were similar. Therefore, one DGGE profile was analyzed per site. Cluster analysis of the profiles showed that shrimps were grouped separately from water and sediments (Fig. 2). DGGE profiles of shrimp bacteria sampled in June formed a separate cluster from those sampled in August, suggesting a seasonal effect on shrimp DGGE banding profiles. For water and sediments, the seasonal effect was not obvious since the DGGE profiles of the two sampling periods grouped partly together. It should be noted that some samples with distant geographic location such as shrimp samples collected in August from the third site in Lake Nokoue (ShN3-Aug) and the second site in Lake Aheme (ShA2-Aug) displayed high (92\%) similarity (see Fig. 2). Numerical analysis of the DGGE profiles based on the relative height intensity of each band indicated lower values of Shannon index of diversity $\left(\mathrm{H}^{\prime}\right)$ and Simpson index of diversity (1-D) in shrimp samples compared to water or sediment samples during both sampling periods (see Fig. S2). The diversity indices were higher in June shrimps than in August shrimps, but were similar in water and sediment samples during both periods. The values of the 

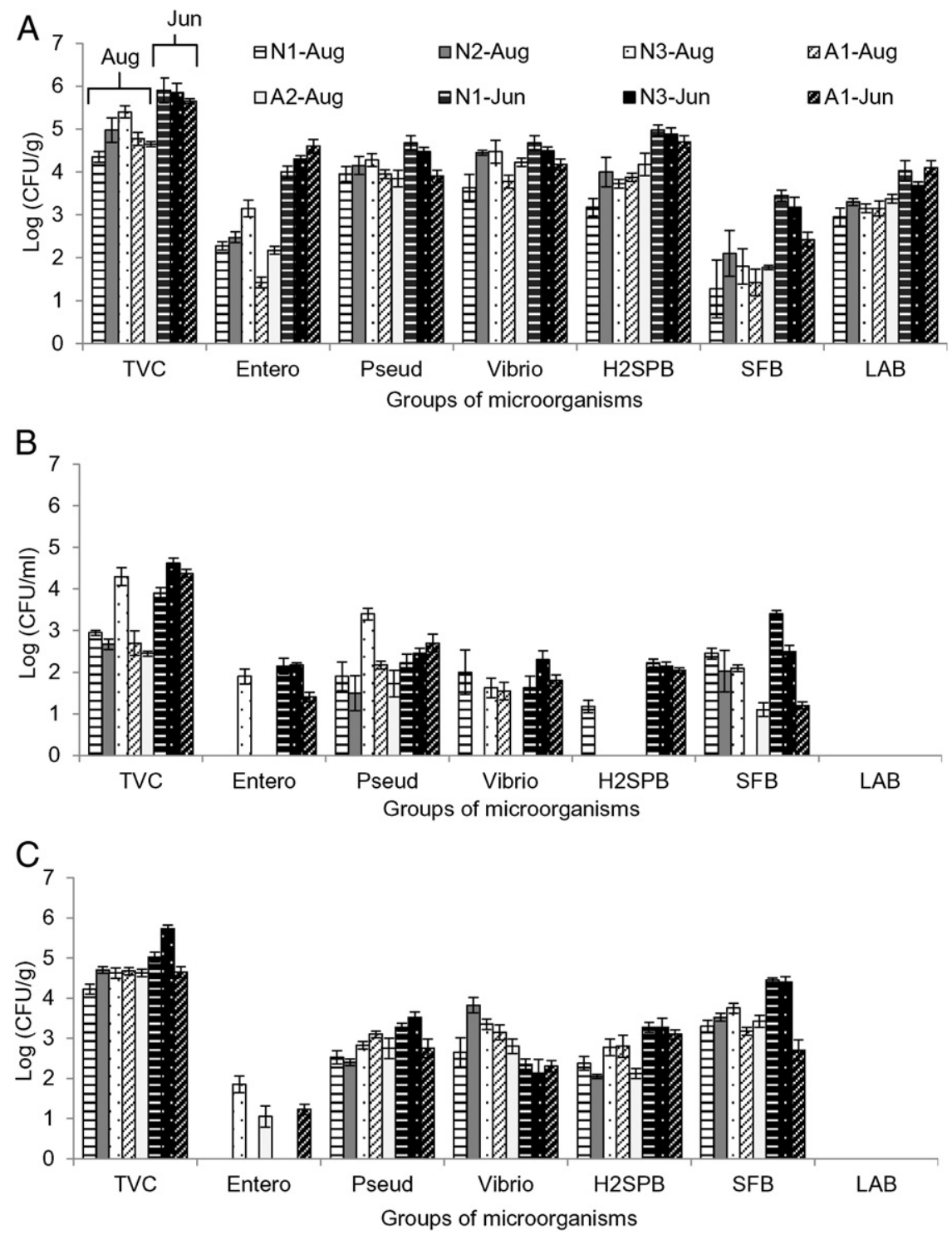

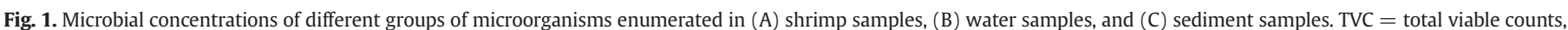

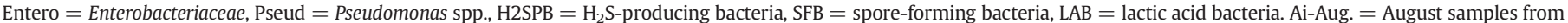
site I in Lake Aheme; Ni-Jun. = June samples from site I in Lake Nokoue. Bars represent the standard deviation of four independent samples.

diversity indices suggest that the bacterial community was less diverse in shrimp samples than in water or sediment samples.

\subsection{Bacterial community analysis by clone libraries}

After discarding the chimeric sequences, the number of sequences analyzed per sample ranged from 55 to 112 (Table 2). Based on RDP Classifier ( $80 \%$ confidence level), the number of phyla ranged from 1 (in August shrimp from lake Nokoue: ShN1-Aug) to 11 in the sediment sample (SeN1-Jun) (Fig. 3A). The proportion of unclassified bacteria was relatively high in the sediment sample (SeN1-Jun) (20\% of the clone library, $n=96)$, but low in other samples $(0-2 \%)$. The most dominant phylum in shrimp samples from Lake Nokoue (both sampling periods) and the water sample from the same lake was Firmicutes. The phylum Firmicutes was however not recovered from the clone library of the sediment sample collected at the same site in the same lake. In contrast, the sediment sample was dominated by the phylum Proteobacteria $(53 \%$ of the clone library, $n=96)$. Proteobacteria predominated in shrimp sample from lake Aheme (ShA1-Jun) (82\% of the clone library, $n=112$ ). Proteobacteria was the second most abundant phylum in water sample (WN1-Jun) (18\% of the clone library, $n=83$ ) and the third most abundant in shrimp from Lake Nokoue sampled in June (ShN1-Jun) (10\% of the clone library, $n=83$ ). However, Proteobacteria members were not evenly distributed within the classes of the phylum among the libraries (Fig. 3B). Alphaproteobacteria were the most abundant Proteobacteria in the water sample (47\% of proteobacterial clones in the sample, $n=15$ ) while they represent the least abundant Proteobacteria in the sediment sample (10\% of proteobacterial clones in the sample, $n=51$ ). Gammaproteobacteria were the most abundant Proteobacteria in the sediment sample (35\% of proteobacterial clones in the sample, $n=51$ ) followed by Deltaproteobacteria (29\%). However, Deltaproteobacteria were not recovered from the water sample. Shrimp samples were mainly dominated by Gammaproteobacteria.

With a $3 \%$ similarity cut-off (sequence similarity $\geq 97 \%$ ), the sequences were assigned to operational taxonomic units (OTU) varying between 5 and 77 OTUs per sample (Table 2). The coverage index ranged between 33\% (SeN1-Jun) and 98\% (ShN1-Aug). In agreement with the DGGE analysis, the Shannon index $\left(\mathrm{H}^{\prime}\right)$ and the Simpson index (1-D) of diversity of the clone libraries were higher in the sediment and water samples than in shrimp samples. Within the shrimp samples, the indices of diversity were higher in the June samples than in the August samples, which is consistent with the DGGE results. 


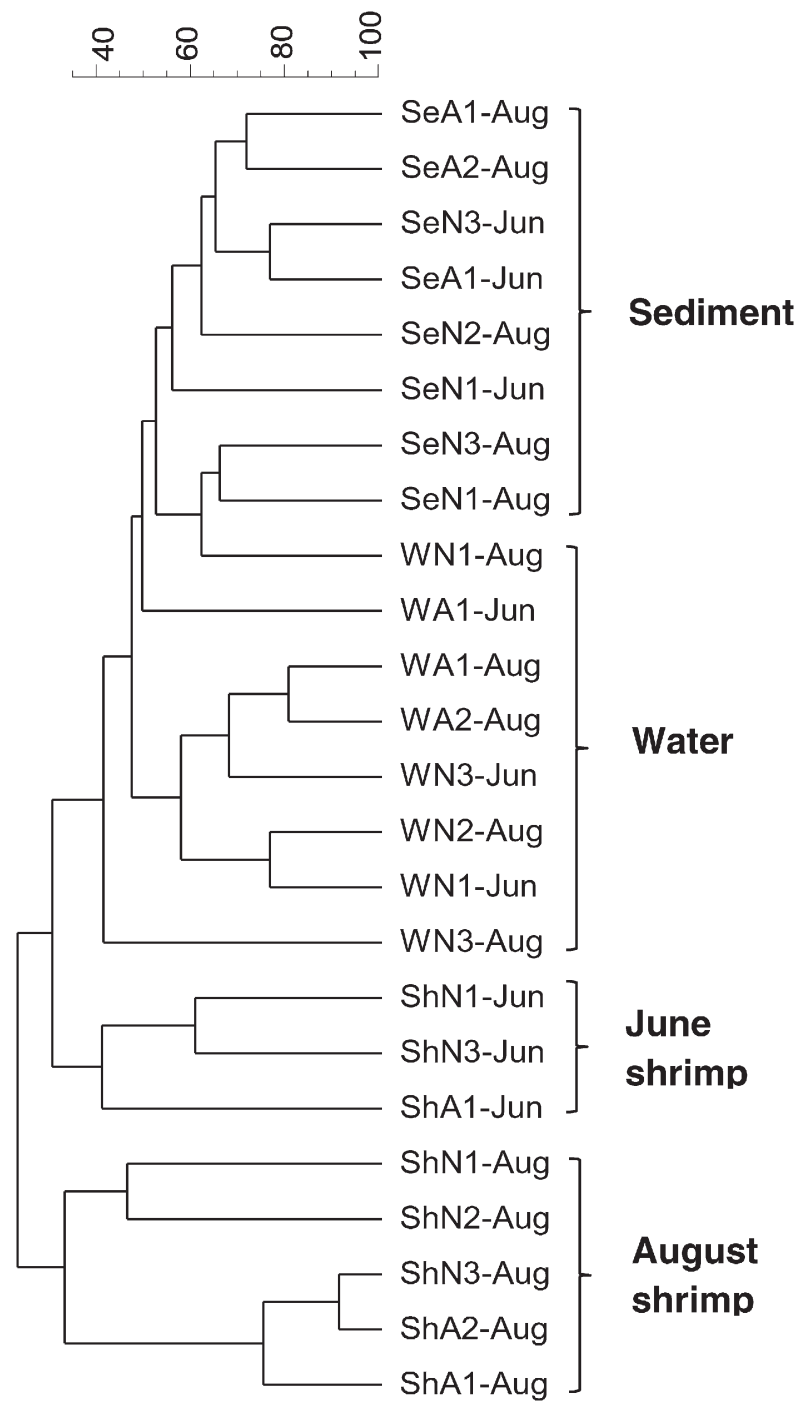

Fig. 2. Clustering analysis of DGGE profiles of sediment, water and shrimp sampled in June and August from Lake Nokoue and Lake Aheme. Se = sediment; $\mathrm{W}=$ water; $\mathrm{Sh}=$ shrimp, $\mathrm{Ni}=$ site $\mathrm{I}$ in Lake Nokoue, $\mathrm{Ai}=$ site $\mathrm{i}$ in Lake Aheme, Jun. = sampling period (June) and Aug. $=$ August.

\subsection{Phylogenetic affiliation of identified OTUs}

By combining all the sequences from the 5 clone libraries, and discarding identical sequences using Mothur software, 424 unique sequences were obtained and assigned to 159 OTUs at 0.03 distance (sequence similarity $\geq 97 \%$ ). Twenty two out of the 159 OTUs were considered as unclassified bacteria at $80 \%$ confidence threshold with the RDP Classifier. A BLAST search was performed on the representative sequence of each of the 137 remaining OTUs. Of the 137 OTUs, 38 (28\%) exhibited $<97 \%$ similarity with the sequences available in the GenBank, and therefore may represent novel species. For the OTUs showing $\geq 97 \%$ similarity with their closest relatives in the GenBank and belonging to shrimp clone libraries, a phylogenetic tree was constructed using the identities of these closest relatives (Fig. 4). The identities of OTUs belonging to the water and the sediment clone libraries are shown in Table S1.

In clone libraries of the shrimps (Fig. 4), a cluster was represented by lactobacillales namely members of the families Enterococcaceae, Streptococcacaea, and Leuconostocaceae (Fig. 4). OTUs from shrimps sampled in June were closely related to species belonging to the genera Vagococcus (OTUs 5, 90, and 102), Enterococcus (OTU32), and Lactococcus (OTUs 8 and 22), while OTU6 from shrimps sampled in August was closely related to Carnobacterium sp. Three OTUs recovered from shrimps sampled in June were classified in the family Staphylococcaceae. One OTU (OTU3 from shrimps sampled in August) was closely related to Bacillus cereus and two others (OTUs 15 and 27) were closely related to members of the family Planococcaceae. In the water library (Table S1), LAB and Staphylococcaceae were not recovered. The dominant members of Firmicutes were Exiguobacterium species.

As for Proteobacteria, two OTUs (OTUs 16 and 24) belonging to Acinetobacter species were recovered. OTU34 from shrimps sampled in June in Lake Aheme fell into the family Shewanellaceae. The biggest cluster was represented by Enterobacteriaceae. OTUs assigned to the phylum Proteobacteria recovered from water or sediment clones libraries clustered mainly with uncultured members of the phylum (Table S1).

In shrimp clone libraries (Fig. 4), only the phylum Actinobacteria represented by Corynebacterium casei was recovered in addition to the phyla Firmicutes and Proteobacteria.

In water or sediment clones libraries recovered OTUs were mainly closely related to uncultured bacteria and clustered in different phyla such as Actinobacteria, Planctomycetes, Acidobacteria, Chloroflexi, Verrumicrobia, Cyanobacteria, Gemmatimonadetes, Deinococcus-Thermus (Table S1).

Note that at 0.03 phylogenetic distance (species level), among OTUs from water, sediment and shrimps sampled at the same site the same day (June sampling), only one OTU (OTU19, Table S1) closely related to uncultured Xanthomonadales (Gammaproteobacteria) was shared between the bacterial community of water and that of sediment. There was no overlap between OTUs from shrimps and those from sediment or water.

\subsection{Bacterial isolates identities}

The identities of bacterial isolates from PCA plates of the five cloned samples are shown in Table 3. The family Staphylococcaceae represented by Staphylococcus spp. and Macrococcus caseolyticus, also identified by cloning analysis, predominated in shrimp sampled in June. Bacillus spp. were identified in water and sediment sampled in June and in shrimp sampled in August. Other Bacillales such as Exiguobacterium indicum and Kurthia gibsonii were also identified in shrimp samples.

Table 2

Number of sequences analyzed, richness and diversity indices of the clones libraries.

\begin{tabular}{|c|c|c|c|c|c|}
\hline Samples & $\begin{array}{l}\text { Number of sequences } \\
\text { analyzed }\end{array}$ & $\begin{array}{l}\text { Number of OTUs } \\
\text { (similarity } \geq 97 \% \text { ) }\end{array}$ & $\begin{array}{l}\text { Coverage index } \\
\text { (C) }(\%)\end{array}$ & $\begin{array}{l}\text { Shannon index } \\
\left(\mathrm{H}^{\prime}\right)^{\mathrm{a}}\end{array}$ & $\begin{array}{l}\text { Simpson index } \\
(1-D)^{\mathrm{a}}\end{array}$ \\
\hline ShN1-Jun & 83 & 19 & 90.4 & $2.36(2.13,2.59)$ & $0.87(0.83,0.91)$ \\
\hline ShA1-Jun & 112 & 20 & 89.3 & $1.92(1.67,2.17)$ & $0.76(0.70,0.82)$ \\
\hline ShN1-Aug & 55 & 5 & 98.0 & $1.06(0.85,1.27)$ & $0.60(0.53,0.67)$ \\
\hline WN1-Jun & 83 & 43 & 60.2 & $3.16(2.86,3.46)$ & $0.91(0.87,0.96)$ \\
\hline SeN1-Jun & 96 & 77 & 32.6 & $4.25(4.09,4.41)$ & $0.99(0.98,1.00)$ \\
\hline
\end{tabular}

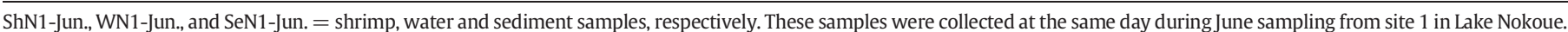

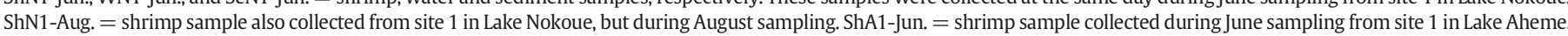

a $95 \%$ confidence interval lower bound and upper bound are shown in parentheses. 

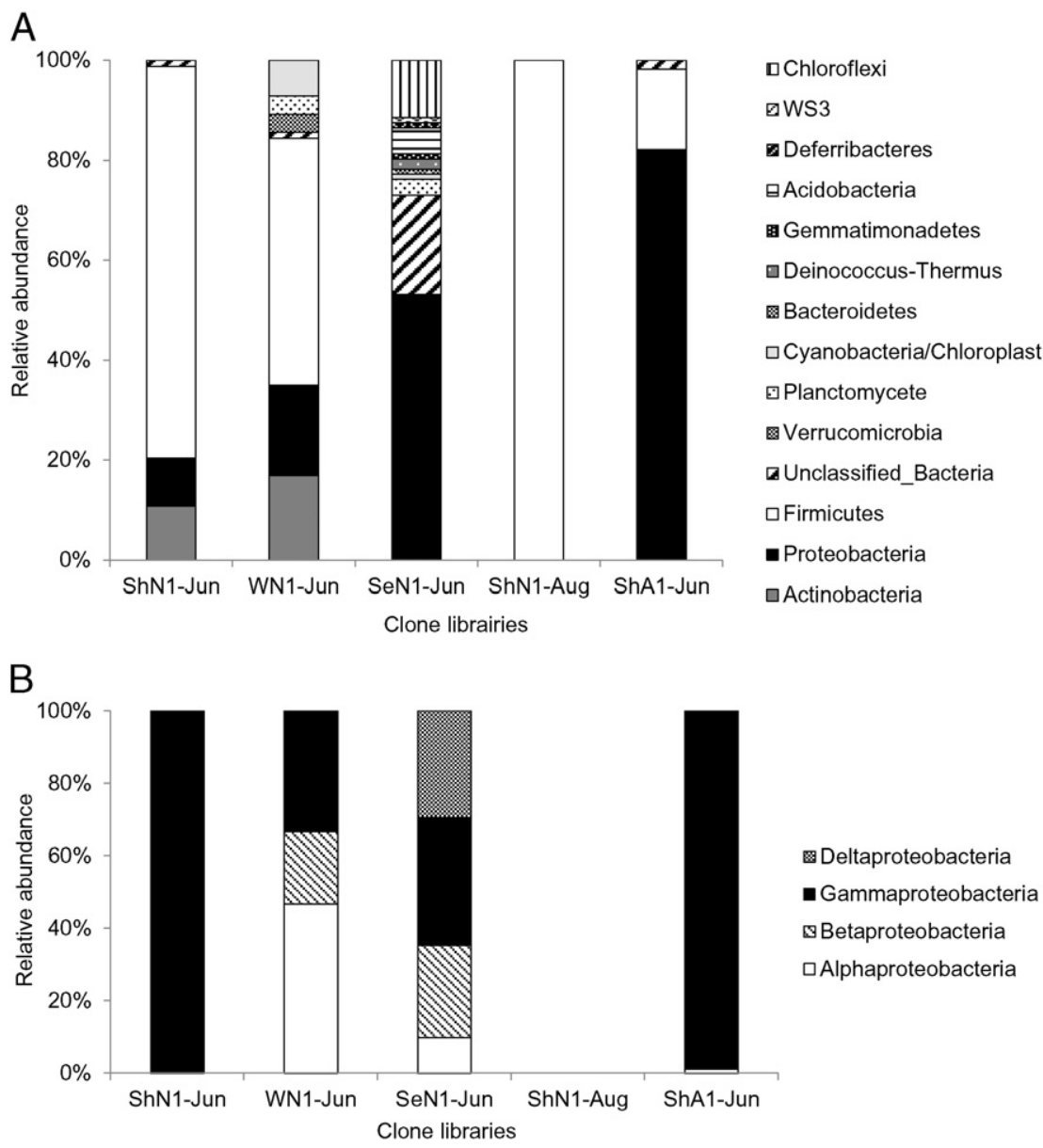

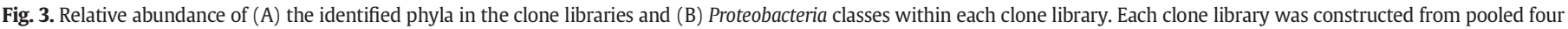
genomic DNA samples. For details about the samples names, see Table 2.

LAB represented by species identified by cloning analysis, namely Lactococcus garvieae (OTU8), Enterococcus faecalis (OTU32) and other species such as Pediococcus pentosaceus, and Enterococcus spp. were identified in all shrimp samples. Isolates belonging to Enterobacteriaceae were identified as Pantoea ananatis, Serratia marcescens, Escherichia fergusonii in shrimp sampled in June from Lake Aheme, Proteus vulgaris in shrimp sampled in June from Lake Nokoue, and Enterobacter spp. in water sampled in June. Bacteria described as being opportunistic pathogenic, namely Pseudomonas stutzeri (Potvliege et al., 1987) and Stenotrophomonas maltophilia (Denton and Kerr, 1998) were also identified in the water sample.

\section{Discussion}

The present study aimed to determine bacterial concentration and diversity in tropical brackish water shrimps and the relationship between the microbiota of the shrimps and that of the surrounding water and sediment.

\subsection{Bacterial concentration in shrimp, water and sediment}

The initial total aerobic counts in shrimps obtained in this study is in agreement with earlier observations that in general, tropical shrimps carry high (5-6 log CFU/g) initial counts of bacteria (ICMSF, 2005). The initial concentration of $\mathrm{H}_{2} \mathrm{~S}$-producing bacteria (4 log $\mathrm{CFU} / \mathrm{g}$ ) obtained in tropical shrimps from India (Penaeus indicus) (Jeyasekaran et al., 2006) is the range of the initial concentration of $\mathrm{H}_{2} \mathrm{~S}$-producing bacteria obtained in this study (3.2-5.0 log CFU/g). However, we found higher initial concentration of LAB (3.0-4.1 log CFU/g) in tropical brackish water shrimp than in the Indian shrimp (2 log CFU/g) (Jeyasekaran et al., 2006). The higher initial bacterial concentration in shrimp in comparison to water or sediments might be explained by a higher proportion of cultivable bacteria associated with shrimps. In fact, the majority of bacteria associated with environmental samples is not cultivable under laboratory conditions (Stevenson et al., 2004). Analyzing the microbial community of water and white shrimp (Litopenaeus vannamei), Johnson et al. (2008) also found that the microbial concentration in shrimp samples was higher than in water. Regarding other seafood species, Del'Duca et al. (2015) also reported higher bacterial concentration in tilapia (Oreochromis niloticus) than in water or sediment. During August sampling, the microbial concentration (TVC) in shrimps collected from the site 3 in Lake Nokoue (N3, see Fig. S1 in supplemental data) was significantly higher than the microbial concentration in shrimps collected from any other site (Fig. 1A). Similarly, Enterobacteriaceae concentration in shrimp, water and sediment from this site was significantly higher. A possible reason for this difference is that this site is located in the vicinity of the village of Ganvié where people live in pole-houses above the lake.

\subsection{Bacterial diversity in shrimp, water and sediment}

Although in our DGGE analysis, we assumed that each band is a bacterial species, it has been reported that one band might include different bacterial species due to co-migration of DNA fragments different in sequences and that multiple bands can be displayed for only one species (De Araujo and Schneider, 2008; Ercolini, 2004). However, it seems that the amplification of hypervariable V6-V8 regions of $16 \mathrm{~S}$ rDNA performed in the present study leads to less multiple bands for a single 


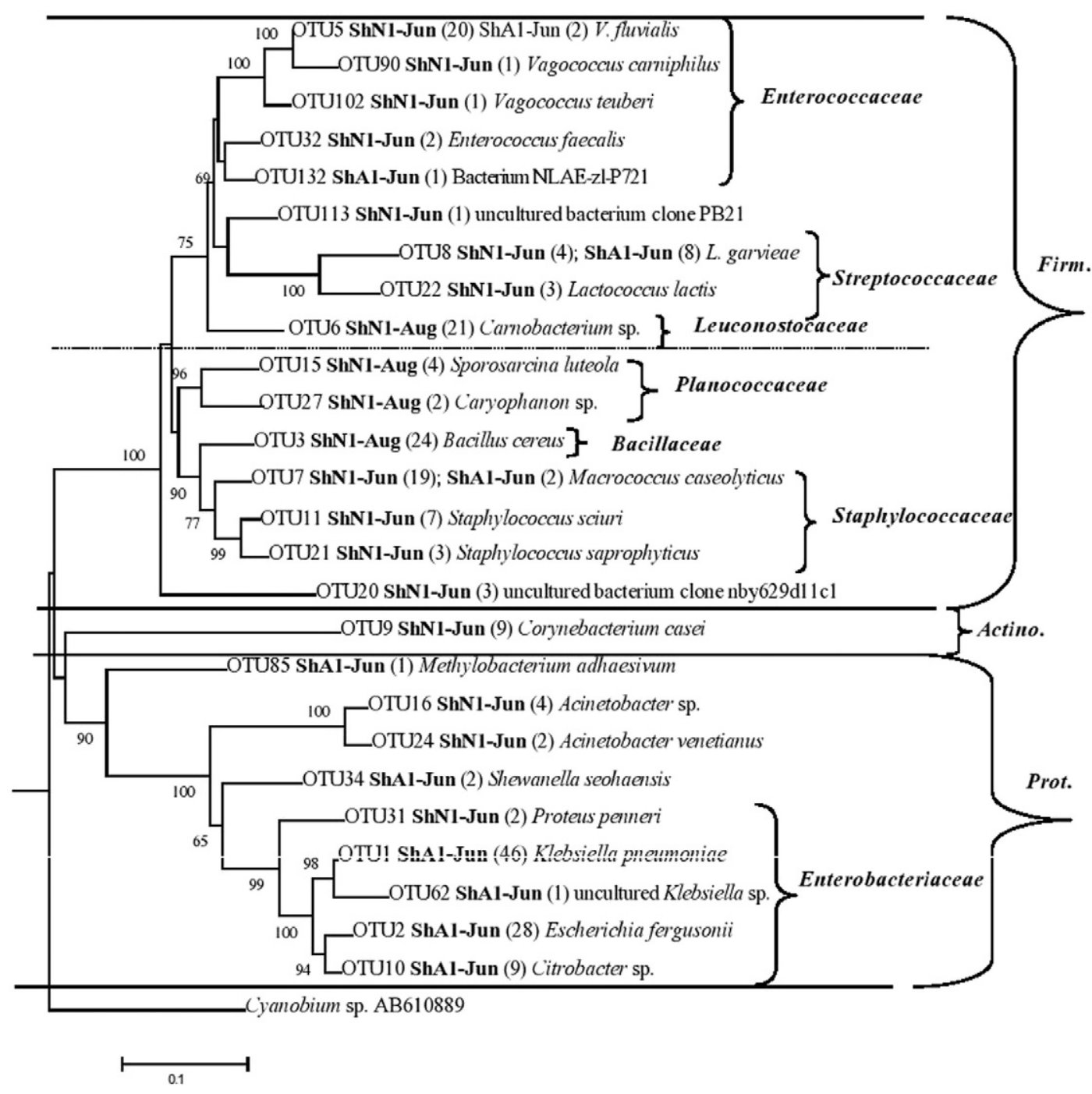

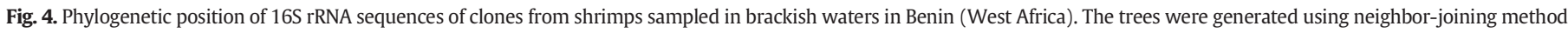

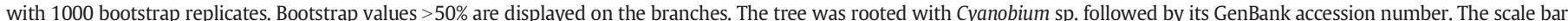

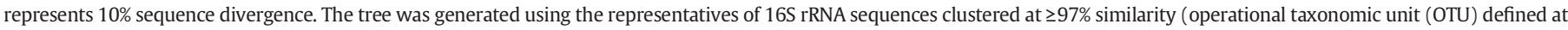

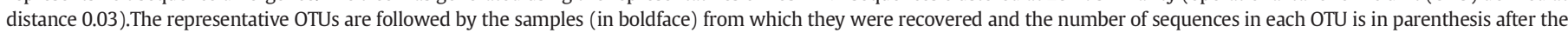

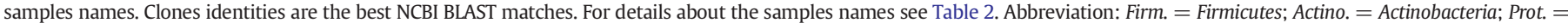
Proteobacteria. Each clone library was constructed from pooled four genomic DNA samples.

species. For example, De Araujo and Schneider (2008) did not observe multiple bands in pure culture amplicons produced with the V6-V8 primer pairs, but pure culture V3 amplicons of some bacterial species displayed multiple bands in their DGGE profile.

In addition, as in several previous studies (Adrados et al., 2014; Dong and Reddy, 2010; Kielak et al., 2013; Thavamani et al., 2012), we used number of bands and the relative intensity of each band in the DGGE profile to determine diversity indices. It is important to note that the assumption that the relative intensity of each band gives the relative abundance of each species can hold only if the procedure of genomic DNA extraction and amplification has the same efficiency for all different species (De Araujo and Schneider, 2008; Duarte et al., 2012; Fromin et al., 2002).

The two molecular methods used in this study (PCR-DGGE and clone libraries) revealed that shrimps sampled in June had higher microbial diversity than in August. The salinity of the waters (ca. $12.9 \mathrm{~g} / \mathrm{L}$ in June and $2.5 \mathrm{~g} / \mathrm{L}$ in August) and their temperature $\left(26.8^{\circ} \mathrm{C}\right.$ in June and $24.2{ }^{\circ} \mathrm{C}$ in August) are environmental parameters that could explain this difference. It has been documented that environmental factors can affect the composition of intestinal bacteria of invertebrates (Chaiyapechara et al., 2012; Hagi et al., 2004; Harris, 1993; Sullam et al.,
2012). Variation in bacterial composition of shrimps sampled in the same period (June) was also found in this study. Chaiyapechara et al. (2012) also found differences in species composition among individual shrimps harvested from the same farm. This suggests that other factors than environmental factors might influence the composition of bacteria associated with shrimps. For instance, Rungrassamee et al. (2013) showed that there was difference in the bacterial population associated with shrimps (Penaeus monodon) at different developmental stages. These findings suggest that monitoring of microbiological quality of shrimps should take into consideration spatiotemporal variations.

LAB were the most abundant group of Firmicutes found in shrimp samples in the present work. LAB were mainly represented by L. garvieae, Vagococcus fluvialis, E. faecalis, and Carnobacterium spp. Jaffres et al. (2009) also found that Carnobacterium spp., Vagococcus spp., and Enterococcus spp. were the dominant bacterial strains of the spoilage microbiota of tropical cooked and peeled shrimps, Penaeus vannamei. Dalgaard et al. (2003) also isolated L. garvieae from spoilage microbiota of warm-water cooked and brined shrimps. Carnobacterium maltaromaticum was found to be responsible for strong and rapid spoilage of cooked whole tropical shrimps (P. vannamei) stored under modified atmosphere packaging (Mace et al., 2014). 
Table 3

Identity of isolates randomly selected from plate count agar plates (reported as total viable counts) as revealed by $16 \mathrm{~S}$ rRNA sequencing.

\begin{tabular}{|c|c|c|c|}
\hline Samples & $\begin{array}{l}\text { Number of } \\
\text { isolates }\end{array}$ & $\begin{array}{l}\text { \% Similarity and GenBank } \\
\text { closest relatives }\end{array}$ & $\begin{array}{l}\text { GenBank } \\
\text { accession } \\
\text { number }\end{array}$ \\
\hline \multirow[t]{12}{*}{ ShN1-Jun } & \multirow[t]{12}{*}{$(n=12)$} & 99\% Staphylococcus sciuri & KP181616 \\
\hline & & $100 \%$ Staphylococcus sciuri & KP181617 \\
\hline & & 97\% Staphylococcus sciuri & KP181618 \\
\hline & & 99\% Staphylococcus sciuri & KP181619 \\
\hline & & $100 \%$ Staphylococcus xylosus & KP181620 \\
\hline & & 98\% Staphylococcus sp. & KP181621 \\
\hline & & 100\% Lactococcus garvieae & KP181622 \\
\hline & & 98\% Kurthia gibsonii & KP181623 \\
\hline & & 99\% Pediococcus pentosaceus & KP181624 \\
\hline & & $100 \%$ Proteus vulgaris & KP181625 \\
\hline & & 99\% Macrococcus caseolyticus & KP181626 \\
\hline & & 99\% Exiguobacterium indicum & KP181627 \\
\hline \multirow[t]{5}{*}{ WN1-Jun } & \multirow[t]{5}{*}{$(n=5)$} & $100 \%$ Enterobacter ludwigii & KP181628 \\
\hline & & $100 \%$ Enterobacter sp. & KP181629 \\
\hline & & $100 \%$ Pseudomonas stutzeri & KP181630 \\
\hline & & $100 \%$ Stenotrophomonas maltophilia & KР181631 \\
\hline & & $100 \%$ Bacillus pumilus & KP181632 \\
\hline \multirow[t]{3}{*}{ SeN1-Jun } & \multirow[t]{3}{*}{$(n=3)$} & $100 \%$ Bacillus licheniformis & KP181633 \\
\hline & & $100 \%$ Bacillus megaterium & KР181634 \\
\hline & & $100 \%$ Bacillus stratosphericus & KP181635 \\
\hline \multirow[t]{6}{*}{ ShN1-Aug } & \multirow[t]{6}{*}{$(n=6)$} & $100 \%$ Bacillus thuringiensis & KP181636 \\
\hline & & $100 \%$ Bacillus amyloliquefaciens & KP181637 \\
\hline & & 99\% Enterococcus casseliflavus & KP181638 \\
\hline & & $100 \%$ Enterococcus faecalis & KР181639 \\
\hline & & $100 \%$ Enterococcus faecalis & KP181640 \\
\hline & & $100 \%$ Kurthia gibsonii & KР181641 \\
\hline \multirow[t]{9}{*}{ ShA1-Jun. } & \multirow[t]{9}{*}{$(n=9)$} & 99\% Staphylococcus nepalensis & КР181642 \\
\hline & & 100\% Staphylococcus cohnii & KP181643 \\
\hline & & 100\% Staphylococcus sp. & KP181644 \\
\hline & & 99\% Macrococcus caseolyticus & KP181645 \\
\hline & & 99\% Pantoea ananatis & KP181646 \\
\hline & & $100 \%$ Serratia marcescens & KP181647 \\
\hline & & $100 \%$ Kurthia gibsonii & KP181648 \\
\hline & & $100 \%$ Escherichia fergusonii & KP181649 \\
\hline & & 95\% Enterococcus sp. & KP181650 \\
\hline
\end{tabular}

The family Staphylococcaceae represented another member of Firmicutes recovered from shrimps sampled in June. The genus Staphylococcus has been detected in brown shrimps (Crangnon crangnon) (Broekaert et al., 2013) and in raw frozen black tiger shrimp imported into Denmark from Vietnam (Noor Uddin et al., 2013). The most common pathogenic species (Staphylococcus aureus) was not detected in the present work. However, Staphylococcus sciuri identified in our study has been reported in the same country (Benin) to cause a nosocomial bacteremia outbreak in hospitalized patients (Ahoyo et al., 2013). To our knowledge, this is the first time M. caseolyticus has been detected in shrimps (Penaeus notialis).

Like in several previous studies on shrimp microbial diversity (Chaiyapechara et al., 2012; Johnson et al., 2008; Liu et al., 2011; Rungrassamee et al., 2014; Oxley et al., 2002), we found Proteobacteria, specifically members of the class Gammaproteobacteria to be the most abundant bacteria in our clone library for shrimp sampled in June in Lake Aheme. However, Proteobacteria were less abundant in the clone library for shrimp sampled in June in Lake Nokoue. Members of Proteobacteria namely Klebsiella pneumoniae (Choudhury and Kumar, 1998), Acinetobacter spp. (Broekaert et al., 2013; Heinsz et al., 1988; Liu et al., 2011) have been previously detected in shrimps. Our study identified for the first time Shewanella seohaensis in shrimps. This species was recently identified in tidal flat sediment samples in Korea as a novel species of the genus Shewanella (Yoon et al., 2012).

C. casei was isolated for the first time in cheese (Brennan et al., 2001). To our knowledge, this is the first time that this organism has been detected in penaeid shrimps.

The identification of some isolates randomly picked from plate counts agar (PCA) (Table 3 ) of shrimp samples revealed some bacteria such as L. garvieae, E. fergusonii, P. vulgaris, E. faecalis, and members of the family Staphylococcaceae (Staphylococcus spp. and M. caseolyticus), which were also detected in the clone libraries of shrimp samples. The family Staphylococcaceae was not targeted when enumerating various groups of microorganisms by plating (see Fig. 1). However, members of this family were identified from our PCA plates by 16S rRNA gene sequencing (Table 3). Also some identified isolates from our PCA plates, namely K. gibsonii and E. indicum (Gram-positive non spore-forming bacteria) are not members of other groups of microorganisms enumerated. This might explain the observed difference between TVC counts and the summation of the counts of other groups of microorganisms enumerated (data not shown).

\subsection{Relationship between the microbiota of the shrimps and that of the surrounding water and sediment}

In the present study, we found that at species level, distinct bacterial communities were associated with water, sediment and shrimps, sampled at the same site and day. Although limited numbers of clone libraries for water and sediment were used in this study, some previous studies have also reported different bacterial assemblages between water and sediment samples (Cole et al., 2013; Feng et al., 2009). In our study, one can argue that the relatively low percentage of coverage of sediment and water clone libraries at species level ( 0.03 phylogenetic distance) (Table 2) could justify the low overlap found between shrimp bacterial communities and that of their aquatic environment. However, even at family level ( 0.10 phylogenetic distance) where the coverage of the water clone library is $85 \%$ (data not shown), only one OTU, the family Moraxellaceae, is shared between shrimps and water samples. At order level ( 0.15 phylogenetic distance) where the coverage of the sediment clone library is $71 \%$ (data not shown), still no OTU is shared between shrimp and sediment samples. These findings suggest that monitoring of the microbiological quality of aquatic environments might not be enough to get insight into the microbiological quality of shrimps.

In conclusion, this study combined culture-dependent and cultureindependent methods to determine bacterial concentration and diversity in freshly caught tropical brackish water shrimps P. notialis. Also the relationship between the bacterial concentration and diversity of shrimps and that of their surrounding of water and sediment was investigated. The study contributes to the knowledge of the microbiota of fresh tropical shrimps. It also shows that the overlap between tropical shrimp microbiota and that of their surroundings of brackish water or sediment is low.

Thus, bacterial community of tropical brackish water shrimps cannot be predicted from the microbiota of their aquatic environment.

Supplementary data to this article can be found online at http://dx. doi.org/10.1016/j.ijfoodmicro.2015.11.013.

\section{Acknowledgments}

This research was supported by The Netherlands Universities Foundation For International Cooperation, project NPT/BEN/263.

\section{References}

Adite, A., Van Thielen, R., 1995. Ecology and fish catches in natural lakes of Benin, West Africa. Environ. Biol. Fish 43, 381-391.

Adrados, B., Sánchez, O., Arias, C.A., Becares, E., Garrido, L., Mas, J., Brix, H., Morató, J., 2014. Microbial communities from different types of natural wastewater treatment systems: vertical and horizontal flow constructed wetlands and biofilters. Water Res. 55, 304-312.

Ahoyo, T.A., Yehouenou, P.E., Baba-Moussa, L., Attolou, G.A., Boco, M., Dramane, K.L., Aminou, T., 2013. Staphylococcus sciuri outbreak at tertiary hospital in Benin. J. Med. Microbiol. Diagn. 2, 1-5.

Altschul, S.F., Gish, W., Miller, W., Myers, E.W., Lipman, D.J., 1990. Basic local alignment search tool. J. Mol. Biol. 215, 403-410.

Alvarez, R.J., 1983. Frequency and distribution of bacterial flora of penaeid shrimp. Caribb. J. Sci. 19, 43-48. 
Bai, Y., Shi, Q., Wen, D., Li, Z., Jefferson, W.A., Feng, C., Tang, X., 2012. Bacterial communities in the sediments of Dianchi Lake, a partitioned eutrophic waterbody in China. PLoS One 75, e37796.

Bekele, A.Z., Koike, S., Kobayashi, Y., 2011. Phylogenetic diversity and dietary association of rumen treponema revealed using group-specific $16 \mathrm{~S}$ rRNA gene-based analysis. FEMS Microbiol. Lett. 316, 51-60.

Brennan, N.M., Brown, R., Goodfellow, M., Ward, A.C., Beresford, T.P., Simpson, P.J., Fox, P.F., Cogan, T.M., 2001. Corynebacterium mooreparkense sp. nov. and corynebacterium casei sp. nov., isolated from the surface of a smear-ripened cheese. Int. J. Syst. Evol. Microbiol. 51, 843-852.

Broekaert, K., Heyndrickx, M., Herman, L., Devlieghere, F., Vlaemynck, G., 2013. Molecular identification of the microbiota of peeled and unpeeled brown shrimp (Crangon crangon) during storage on ice and at $7.5^{\circ} \mathrm{C}$. Food Microbiol. 36, 123-134.

Chaiyapechara, S., Rungrassamee, W., Suriyachay, I., Kuncharin, Y., Klanchui, A. Karoonuthaisiri, N., Jiravanichpaisal, P., 2012. Bacterial community associated with the intestinal tract of P. monodon in commercial farms. Microb. Ecol. 63, 938-953.

Choudhury, P., Kumar, R., 1998. Multidrug-and metal-resistant strains of Klebsiella pneumoniae isolated from Penaeus monodon of the coastal waters of deltaic sundarban. Can. J. Microbiol. 44, 186-189.

Cole, J.K., Peacock, J.P., Dodsworth, J.A., Williams, A.J., Thompson, D.B., Dong, H., Wu, G., Hedlund, B.P., 2013. Sediment microbial communities in Great Boiling Spring are controlled by temperature and distinct from water communities. ISME J. 7, 718-729.

Dabadé, D.S., den Besten, H.M.W., Azokpota, P., Nout, M.J.R., Hounhouigan, D.J., Zwietering, M.H., 2014. Quality perceptions of stakeholders in Beninese exportoriented shrimp chain. J. Food Prot. 77, 1642-1648.

Dalgaard, P., Vancanneyt, M., Vilalta, N.E., Swings, J., Fruekilde, P., Leisner, J.J., 2003. Identification of lactic acid bacteria from spoilage associations of cooked and brined shrimps stored under modified atmosphere between $0{ }^{\circ} \mathrm{C}$ and $25{ }^{\circ} \mathrm{C}$. J. Appl. Microbiol. 94, 80-89.

De Araujo, J.C., Schneider, R.P., 2008. DGGE with genomic DNA: suitable for detection of numerically important organisms but not for identification of the most abundant organisms. Water Res. 42, 5002-5010.

Del'Duca, A., Cesar, D.E., Abreu, P.C., 2015. Bacterial community of pond's water, sediment and in the guts of tilapia (Oreochromis niloticus) juveniles characterized by fluorescent in situ hybridization technique. Aquac. Res. 46, 707-715.

Denton, M., Kerr, K.G., 1998. Microbiological and clinical aspects of infection associated with Stenotrophomonas maltophilia. Clin. Microbiol. Rev. 11, 57-80.

Dong, X., Reddy, G.B., 2010. Soil bacterial communities in constructed wetlands treated with swine wastewater using PCR-DGGE technique. Bioresour. Technol. 101, 1175-1182.

Duarte, S., Cassio, F., Pascoal, C., 2012. Denaturing Gradient Gel Electrophoresis (DGGE)in microbial ecology - insights from freshwaters. In: Magdeldin, S. (Ed.), Gel Electrophoresis - Principles and Basics. InTech, pp. 173-196.

Ercolini, D., 2004. PCR-DGGE fingerprinting: novel strategies for detection of microbes in food. J. Microbiol. Methods 56, 297-314.

Feng, B.W., Li, X.R., Wang, J.H., Hu, Z.Y., Meng, H., Xiang, L.Y., Quan, Z.X., 2009. Bacterial diversity of water and sediment in the changjiang estuary and coastal area of the East China Sea. FEMS Microbiol. Ecol. 70, 236-248.

Fromin, N., Hamelin, J., Tarnawski, S., Roesti, D., Jourdain-Miserez, K., Forestier, N., Teyssier-Cuvelle, S., Gillet, F., Aragno, M., Rossi, P., 2002. Statistical analysis of denaturing gel electrophoresis (DGE) fingerprinting patterns. Environ. Microbiol. 11, 634-643.

FVO (Food and Veterinary Office), 2003. Rapport concernant une mission en République du Bénin du 7 au 11 octobre 2002 concernant les conditions de production et d'exportation vers l'Union Européenne des produits de la pêche. DG (Sanco)/8719/ 2002-MR Final. Available at: http://ec.europa.eu/food/fvo/rep_details_en.cfm?rep_ $\mathrm{id}=888$ (Accessed 16 May 2012)

Gadel, F., Texier, H., 1986. Distribution and nature of organic matter in recent sediments of Lake Nokoué, Benin (West Africa). Estuar. Coast. Shelf Sci. 22, 767-784.

Gram, L., Trolle, G., Huss, H.H., 1987. Detection of specific spoilage bacteria from fish stored at low $\left(0{ }^{\circ} \mathrm{C}\right)$ and high $\left(20^{\circ} \mathrm{C}\right)$ temperatures. Int. J. Food Microbiol. 4, 65-72.

Hagi, T., Tanaka, D., Iwamura, Y., Hoshino, T., 2004. Diversity and seasonal changes in lactic acid bacteria in the intestinal tract of cultured freshwater fish. Aquaculture 234, 335-346.

Harris, J.M., 1993. The presence, nature, and role of gut microflora in aquatic invertebrates: a synthesis. Microb. Ecol. 25, 195-231.

Heinsz, L.J., Harrison, M.A., Leiting, V.A., 1988. Microflora of brown shrimp (Penaeus aztecus) from Georgia coastal waters. Food Microbiol. 5, 141-145.

Hovda, M.B., Lunestad, B.T., Sivertsvik, M., Rosnes, J.T., 2007. Characterisation of the bacterial flora of modified atmosphere packaged farmed Atlantic cod (Gadus morhua) by PCR-DGGE of conserved 16S rRNA gene regions. Int. J. Food Microbiol. 117, 68-75.

ICMSF, 2005. Microbiology in Foods 6: Microbial Ecology of Food Commodities. 2nd ed. Kluwer Academic/Plenum Publishers, New York, NY.

Jaffres, E., Sohier, D., Leroi, F., Pilet, M.F., Prevost, H., Joffraud, J.J., Dousset, X., 2009. Study of the bacterial ecosystem in tropical cooked and peeled shrimps using a polyphasic approach. Int. J. Food Microbiol. 131, 20-29.

Jeyasekaran, G., Ganesan, P., Anandaraj, R., Shakila, R.J., Sukumar, D., 2006. Quantitative and qualitative studies on the bacteriological quality of Indian white shrimp (Penaeus indicus) stored in dry ice. Food Microbiol. 23, 526-533.

Johnson, C.N., Barnes, S., Ogle, J., Grimes, D.J., Chang, Y.J., Peacock, A.D., Kline, L., 2008. Microbial community analysis of water, foregut, and hindgut during growth of Pacific white shrimp, Litopenaeus vannamei, in closed-system aquaculture. J. World Aquacult. Soc. 39, 251-258.

Kielak, A.M., Cretoiu, M.S., Semenov, A.V., Sørensen, S.J., Van Elsas, J.D., 2013. Bacterial chitinolytic communities respond to chitin and $\mathrm{pH}$ alteration in soil. Appl. Environ. Microbiol. 79, 263-272
Lalèyè, P., Niyonkuru, C., Moreau, J., Teugels, G.G., 2003. Spatial and seasonal distribution of the ichthyofauna of Lake Nokoué, Bénin, West Africa. Afr. J. Aquat. Sci. 28, 151-161.

Laplace-Builhé, C., Hahne, K., Hunger, W., Tirilly, Y., Drocourt, J.L., 1993. Application of flow cytometry to rapid microbial analysis in food and drinks industries. Biol. Cell. $78,123-128$.

Lima, L.J., van der Velpen, V., Wolkers-Rooijackers, J., Kamphuis, H.J., Zwietering, M.H., Nout, M.J.R., 2012. Microbiota dynamics and diversity at different stages of industrial processing of cocoa beans into cocoa powder. Appl. Environ. Microbiol. 78, 2904-2913.

Liu, H., Wang, L., Liu, M., Wang, B., Jiang, K., Ma, S., Li, Q., 2011. The intestinal microbial diversity in Chinese shrimp (Fenneropenaeus chinensis) as determined by PCR-DGGE and clone library analyses. Aquaculture 317, 32-36.

Mace, S., Cardinal, M., Jaffrès, E., Cornet, J., Lalanne, V., Chevalier, F., Serot, T., Pilet, M.F., Dousset, X., Joffraud, J.J., 2014. Evaluation of the spoilage potential of bacteria isolated from spoiled cooked whole tropical shrimp (Penaeus vannamei) stored under modified atmosphere packaging. Food Microbiol. 40, 9-17.

Martin, R., Heilig, G.H.J., Zoetendal, E.G., Smidt, H., Rodríguez, J.M., 2007. Diversity of the Lactobacillus group in breast milk and vagina of healthy women and potential role in the colonization of the infant gut. J. Appl. Microbiol. 103, 2638-2644.

Maslin, J.L., Bouvet, Y., 1986. Population dynamics of Corbula trigona (Mollusca) in Lake Aheme, a West African lagoon in Benin. Oikos 46, 292-302.

Maslin, J.L., Pattee, E., 1989. The production of Corbula trigona (Bivalvia) in relation to its demographic strategies in a West African lagoon. Oikos 55, 194-204.

Muyzer, G., De Waal, E.C., Uitterlinden, A.G., 1993. Profiling of complex microbial populations by denaturing gradient gel electrophoresis analysis of polymerase chain reaction-amplified genes coding for 16S rRNA. Appl. Environ. Microbiol. 59, 695-700.

Noor Uddin, G.M., Larsen, M.H., Guardabassi, L., Dalsgaard, A., 2013. Bacterial flora and antimicrobial resistance in raw frozen cultured seafood imported to Denmark. J. Food Prot. 76, 490-499.

Nubel, U., Engelen, B., Felske, A., Snaidr, J., Wieshuber, A., Amann, R.I., Ludwig, W., Backhaus, H., 1996. Sequence heterogeneities of genes encoding 16S rRNAs in Paenibacillus polymyxa detected by temperature gradient gel electrophoresis. J. Bacteriol. 178, 5636-5643.

Oxley, A.P.A., Shipton, W., Owens, L., McKay, D., 2002. Bacterial flora from the gut of the wild and cultured banana prawn, Penaeus merguiensis. J. Appl. Microbiol. 93, 214-223.

Potvliege, C., Jonckheer, J., Lenclud, C., Hansen, W., 1987. Pseudomonas stutzeri pneumonia and septicemia in a patient with multiple myeloma. J. Clin Microbiol. 25, 458-459.

Rahman, M.M., Basaglia, M., Vendramin, E., Boz, B., Fontana, F., Gumiero, B., Casella, S. 2014. Bacterial diversity of a wooded riparian strip soil specifically designed for enhancing the denitrification process. Biol. Fertil. Soils 50, 25-35.

Rudi, K., Maugesten, T., Hannevik, S.E., Nissen, H., 2004. Explorative multivariate analyses of $16 \mathrm{~S}$ rRNA gene data from microbial communities in modified-atmosphere-packed salmon and coalfish. Appl. Environ. Microbiol. 70, 5010-5018.

Rungrassamee, W., Klanchui, A., Chaiyapechara, S., Maibunkaew, S., Tangphatsornruang, S., Jiravanichpaisal, P., Karoonuthaisiri, N., 2013. Bacterial population in intestines of the black tiger shrimp (Penaeus monodon) under different growth stages. PLoS One 8, e60802.

Rungrassamee, W., Klanchui, A., Maibunkaew, S., Chaiyapechara, S., Jiravanichpaisal, P. Karoonuthaisiri, N., 2014. Characterization of intestinal bacteria in wild and domesticated adult black tiger shrimp (Penaeus monodon). PLoS One 9, e91853.

Sanguinetti, C.J., Neto, E.D., Simpson, A.J.G., 1994. Rapid silver staining and recovery of PCR products separated on polyacrylamide gels. Biotechniques 17, 914-921.

Schloss, P.D., Westcott, S.L., Ryabin, T., Hall, J.R., Hartmann, M., Hollister, E.B., Lesniewski, R.A., Oakley, B.B., Parks, D.H., Robinson, C.J., Sahl, J.W., Stres, B., Thallinger, G.G., Van Horn, D.J., Weber, C.F., 2009. Introducing mothur: open-source, platformindependent, community-supported software for describing and comparing microbial communities. Appl. Environ. Microbiol. 75, 7537-7541.

Shamshad, S.I., Kher, U.N., Riaz, M., Zuberi, R., Qadri, R.B., 1990. Shelf life of shrimp (Penaeus merguiensis) stored at different temperatures. J. Food Sci. 55, 1201-1205.

Stevenson, B.S., Eichorst, S.A., Wertz, J.T., Schmidt, T.M., Breznak, J.A., 2004. New strategies for cultivation and detection of previously uncultured microbes. Appl. Environ. Microbiol. 70, 4748-4755.

Sullam, K.E., Essinger, S.D., Lozupone, C.A., O'Connor, M.P., Rosen, G.L., Knight, R., Kilham, S.S., Russell, J.A., 2012. Environmental and ecological factors that shape the gut bacterial communities of fish: a meta-analysis. Mol. Ecol. 21, 3363-3378.

Tamura, K., Peterson, D., Peterson, N., Stecher, G., Nei, M., Kumar, S., 2011. MEGA5: molecular evolutionary genetics analysis using maximum likelihood, evolutionary distance and maximum parsimony methods. Mol. Biol. Evol. 28, 2731-2739.

Thavamani, P., Malik, S., Beer, M., Megharaj, M., Naidu, R., 2012. Microbial activity and diversity in long-term mixed contaminated soils with respect to polyaromatic hydrocarbons and heavy metals. J. Environ. Manag. 99, 10-17.

Vanderzant, C., Nickelson, R., Judkins, P.W., 1971. Microbial flora of pond-reared brown shrimp (Penaeus aztecus). Appl. Microbiol. 21, 916-921.

Villanueva, M.C., Lalèyè, P., Albaret, J.J., Lae, R., de Morais, L.T., Moreau, J., 2006. Comparative analysis of trophic structure and interactions of two tropical lagoons. Ecol. Model. 197, 461-477.

Wang, Q., Garrity, G.M., Tiedje, J.M., Cole, J.R., 2007. Naive Bayesian classifier for rapid assignment of rRNA sequences into the new bacterial taxonomy. Appl. Environ. Microbiol. 73, 5261-5267.

Wright, E.S., Yilmaz, L.S., Noguera, D.R., 2012. DECIPHER, a search-based approach to chimera identification for 16S rRNA sequences. Appl. Environ. Microbiol. 78, 717-725.

Yoon, J.H., Park, S., Jung, Y.T., Lee, J.S., 2012. Shewanella seohaensis sp. nov., isolated from a tidal flat sediment. Antonie Van Leeuwenhoek 102, 149-156.

Ziegler, F., Emanuelsson, A., Eichelsheim, J.L., Flysjö, A., Ndiaye, V., Thrane, M., 2011. Extended life cycle assessment of southern pink shrimp products originating in Senegalese artisanal and industrial fisheries for export to Europe. J. Ind. Ecol. 15, 527-538. 